\title{
Penerapan Pendekatan Pembelajaran Matematika Realistik Untuk Meningkatkan Aktivitas dan Hasil Belajar Siswa Pada Materi Trapesium dan Layang-Layang (The Application of Realistic Mathematics Education in Main Discussion of
Trapesium and Kite to Improve Activities and Learning Outcomes)
}

\author{
Mochammad Andi Lazuardi, Titik Sugiarti, Agustiningsih \\ Prodi PGSD, Jurusan Ilmu Pendidikan, Fakultas Keguruan dan Ilmu Pendidikan, Universitas Jember (UNEJ) \\ Jln. Kalimantan 37, Jember 68121 \\ E-mail : andilazuardi35@gmail.com, titiksugiarti.fkip@unej.ac.id, agustinlusy@yahoo.com \\ DOI: https://doi.org/10.19184/jukasi.v4i3.6149
}

\begin{abstract}
Abstrak
Objek kajian matematika yang cenderung abstrak membutuhkan pendekatan/pembelajaran yang tepat untuk diterapkan pada siswa SD yang tahap perkembangan kognitifnya masih berada pada tahap operasional konkret. Berdasarkan penjelasan tersebut, dalam mengajarkan konsep matematika dibutuhkan benda-benda konkret dan sesuatu yang dapat dibayangkan oleh siswa agar pembelajaran bisa optimal. Pada kenyataannya, aktivitas dan hasil belajar siswa kelas V di SD Antirogo 01 Jember masih rendah. Untuk mengatasi permasalahan tersebut, diterapkan pembelajaran matematika realistik untuk meningkatkan aktivitas dan hasil belajar siswa. Penelitian ini bertujuan untuk menerapkan dan meningkatkan aktivitas serta hasil belajar siswa dengan menerapkan pembelajaran matematika realistik pada pokok bahasan luas trapesium dan layanglayang. Jenis penelitian yang digunakan adalah penelitian tindakan kelas yang terdiri dari 2 siklus, dimana pada siklus I terdiri dari 2 pertemuan dan pada siklus II terdiri dari sekali pertemuan. Metode pengumpulan data yang digunakan adalah dokumentasi, observasi, wawancara, dan tes. Pelaksanaan penelitian ini dilakukan di SDN Antirogo 01 Jember pada semester ganjil tahun pelajaran 2017/2018. Adapun subjek penelitiannya adalah siswa kelas V yang terdiri dari 12 siswa laki-laki dan 14 siswa perempuan. Berdasarkan hasil analisis data, persentase aktivitas belajar siswa meningkat dari 54,94\% pada siklus 1 menjadi $63,65 \%$ pada siklus 2 . Persentase aktivitas guru juga mengalami peningkatan dari $73,84 \%$ pada siklus 1 menjadi $80 \%$ pada siklus 2. Selain itu, penerapan matematika realistik juga dapat menigkatkan hasil belajar siswa. Rata-rata hasil belajar siswa meningkat dari 56,92 pada siklus 1 menjadi 71,15 pada siklus 2 . Ketuntasan belajar siswa juga mengalami peningkatan dari $71,9 \%$ pada siklus 1 menjadi $84,4 \%$ pada siklus 2 .
\end{abstract}

Kata Kunci: pembelajaran matematika realistik, aktivitas belajar, hasil belajar, luas trapesium dan layang-layang

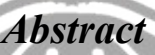

An object of mathematic that tend to abstract need the right approach/learning to be applied for primary students are still at the stage of concrete operations. Based on that, in teaching the concepts of mathematics needed concrete objects and something that can be imagined by the students so that learning can be optimum. In fact, the activity and learning outcomes of fifth grade students at Antirogo 01 Jember is still low. To overcome these problems, applied realistic mathematics education to improve student activity and learning outcomes. The purpose of this research is to analyze and improve student activity and learning outcomes by applying realistic mathematical learning in main discussion of trapesium and kite area. The type of research used is a classroom action research consisting of 2 cycles. In first cycle consisting of 2 meetings and in second cycle, consisting of 1 meeting. Methods of data collection used are documentation, observation, interviews, and tests. The implementation of this research was conducted at SDN Antirogo 01 Jember in the odd semester of the academic year 2017/2018. The subjects of the study are class V students consisting of 12 male students and 14 female students. Based on the results of data analysis, the percentage of student learning activities increased from $54.94 \%$ in cycle 1 to $63.65 \%$ in cycle 2. Percentage of teacher activity also increased from $73.84 \%$ in cycle 1 to $80 \%$ in cycle 2. In addition, the application of realistic mathematics education can also improve students' learning outcomes. The average student learning outcomes increased from 56.92 in the first cycle to 71.15 in cycle 2. Student learning completeness also increased from $71.9 \%$ in cycle 1 to $84.4 \%$ in cycle 2 .

Keywords : realistic mathematics education, student activities, learning outcomes, trapesium and kite area

\section{Pendahuluan}

Matematika adalah salah satu disiplin ilmu yang dapat meningkatkan kemampuan berfikir dan berargumentasi memberikan kontribusi dalam penyelesaian masalah dalam kehidupan sehari-hari maupun dalam dunia kerja serta memberikan dukungan dalam pengembangan ilmu pengetahuan dan teknologi [1].

Pembelajaran matematika di SD umumnya masih konvensional, yakni ceramah, tanya jawab, dan pemberian 
tugas. Selain itu penerapan metode pembelajaran matematika masih berpusat pada guru (teacher oriented), sehingga siswa cenderung pasif. Guru dalam pembelajaran konvensional biasanya lebih menekankan pada penggunaan rumus dan pemberian soal latihan, sehingga siswa hanya terbiasa mengerjakan soal tanpa dilatih untuk berpikir dan memahami konsep. Mengantuk, bermain sendiri, tidak mau mengerjakan soal, bahkan berkelahi saat pembelajaran merupakan akibat dari kurangnya kontribusi aktif siswa dalam proses pembelajaran. Jika telah terjadi demikian, maka tidak ada peningkatan aktivitas belajar matematika dan hasil belajar siswa tidak sesuai dengan yang diharapkan.

Berdasarkan observasi awal yang dilakukan di SDN Antirogo 01 Jember, diperoleh data bahwa tingkat penguasaan siswa terhadap materi pelajaran matematika masih rendah. Hal ini berdasarkan data hasil ulangan sebelumnya pada materi pecahan yang mana banyak siswa masih memperoleh nilai di bawah standar KKM. Kelulusan belajar siswa kelas V tahun pelajaran $2017 / 2018$ pada materi pecahan, dari 26 siswa yang mencapai KKM yang telah ditentukan yaitu 60, ada 16 siswa masih belum memenuhi standar KKM dan sisanya yaitu 10 anak sudah memenuhi kriteria. Oleh karena itu, Guru kelas harus melakukan perbaikan agar nilai-nilai yang masih dibawah KKM tadi bisa terangkat.

Untuk mengatasi permasalahan tersebut perlu dilakukan perbaikan dalam proses pembelajaran, yang diantaranya adalah dengan menciptakan situasi pembelajaran yang menyenangkan, mendorong terjadinya aktivitas, baik siswa itu sendiri maupun bersama siswa lain, serta memberikan kesempatan bagi siswa untuk menemukan kembali ide dan konsep matematika dengan cara mereka sendiri di bawah bimbingan guru. Dengan cara tersebut, diharapkan pembelajaran akan lebih bermakna bagi siswa. Salah satu pembelajaran yang menyenangkan, mendorong aktivitas siswa, serta penemuan ide dan konsep matematika adalah pembelajaran matematika realistik (PMR).

Pembelajaran matematika realistik menggunakan masalah kontekstual sebagai titik tolak dalam belajar matematika. Pembelajaran matematika dengan menggunakan metode PMR pada materi Luas Trapesium dan LayangLayang ini, siswa diajak untuk mempelajari satuan luas, mengenal apa itu trapesium dan layang-layang, menghitung luas trapesium dan layang-layang dengan memperhatikan berbagai objek nyata yang ada di sekitar mereka yang sering mereka lihat dalam kehidupan sehari-hari. Objek nyata ini nantinya akan digunakan sebagai sumber belajar maupun media untuk siswa agar mereka lebih memahami materi pembelajaran yang disampaikan oleh guru. Media digunakan sebagai jembatan untuk siswa agar siswa lebih memahami dan menemukan sendiri konsep-konsep matematika yang diajarkan.

Menurut Sugiarti [2] ada 4 pendekatan yang menggunakan komponen matematisasi horizontal dan matematisasi vertikal: 1) Mekanistik atau pendekatan tradisional, yaitu pendekatan pembelajaran matematika yang lebih memfokuskan pada drill atau latihan menghafal rumus, sedangkan proses matematisasi keduanya tidak tampak. 2) Empristik, lebih menekankan pada matematisasi horizontal dan cenderung mengabaikan matematisasi vertikal. 3)
Strukturalistik, lebih menekankan pada matematisasi vertikal dan cenderung mengabaikan matematisasi horizontal. 4) Realistik, memberikan perhatian yang seimbang antara matematisasi horizontal dan vertikal dan disampaikan secara terpadu kepada siswa.

Rumusan masalah dalam penelitian ini adalah bagaimanakah penerapan pembelajaran matematika realistik, dan bagaimanakah aktivitas serta hasil belajar siswa pada pembelajaran matematika realistik pokok bahasan trapesium dan layang-layang. Penelitian dilakukan dengan tujuan untuk menerapkan dan meningkatkan aktivitas serta hasil belajar siswa dengan menerapkan pembelajaran matematika realistik pada pokok bahasan trapesium dan layang-layang.

\section{Metode Penelitian}

Jenis penelitian yang digunakan dalam penelitian ini adalah penelitian tindakan kelas (PTK). Menurut Hobri [3], PTK merupakan suatu penyelidikan atau kajian untuk memperbaiki pembelajaran dengan mengadakan perbaikan atau perubahan dan mempelajari akibat yang ditimbulkan secara sistematis dan terencana. Arikunto dkk. [4] juga menyatakan bahwa PTK adalah jenis penelitian yang mendeskripsikan proses maupun hasil, yang melakukan penelitian di kelasnya untuk meningkatkan kualitas pembelajarannya. Penelitian ini dilaksanakan dalam 2 siklus yang masing-masing terdiri dari 2 pertemuan.

Penelitian dilaksanakan di SDN Antirogo 01 Jember pada semester ganjil tahun pelajaran 2017/2018. Adapun subjek penelitiannya adalah siswa kelas V dengan total 26 siswa yang terdiri dari 12 siswa laki-laki dan 14 siswa perempuan. Metode pengumpulan data dalam penelitian ini menggunakan metode observasi, tes, wawancara, dan dokumentasi. Hasil observasi aktivitas dan hasil belajar siswa dianalisis secara deskriptif.

Data yang dianalisis dalam penelitian ini adalah sebagai berikut.

a. Aktivitas siswa selama proses pembelajaran matematika realistik

Menurut Depdiknas (dalam Hobri, [3]), persentase keaktifan siswa dihitung menggunakan rumus berikut.

$$
P_{a}=\frac{A}{N} \times 100
$$

Keterangan:

$\mathrm{Pa}=$ persentase keaktifan siswa

$\mathrm{A}=$ jumlah skor yang dicapai

$\mathrm{N}=$ jumlah skor maksimal

Kriteria klasifikasi aktivitas belajar siswa yang telah dimodifikasi dari Masyhud [5] dapat dilihat pada tabel 1 berikut.

Tabel 1. Kriteria Aktivitas Belajar Siswa

\begin{tabular}{|c|c|}
\hline Kriteria Aktivitas Belajar & Rentangan Persentase \\
\hline Sangat Aktif & $80 \leq \mathrm{Pa} \leq 100$ \\
\hline Aktif & $60 \leq \mathrm{Pa}<80$ \\
\hline Cukup Aktif & $40 \leq \mathrm{Pa}<60$ \\
\hline Kurang Aktif & $20 \leq \mathrm{Pa}<40$ \\
\hline
\end{tabular}




\begin{tabular}{|c|c|}
\hline Kriteria Aktivitas Belajar & Rentangan Persentase \\
\hline Sangat Kurang Aktif & $0 \leq \mathrm{Pa}<20$ \\
\hline
\end{tabular}

b. Hasil belajar siswa

Menurut Depdiknas (dalam Hobri, [3]), persentase ketuntasan hasil belajar siswa setelah penerapan pembelajaran matematika realistik, dihitung menggunakan rumus sebagai berikut.

$$
E=\frac{n}{N} x 100
$$

Keterangan:

$\mathrm{E}=$ persentase ketuntasan belajar secara klasikal

$\mathrm{n}=$ jumlah siswa yang tuntas belajar

$\mathrm{N}=$ jumlah seluruh siswa

Kriteria klasifikasi persentase kentuntasan belajar siswa yang telah dimodifikasi dari Masyhud [5] dapat dilihat pada Tabel 2 berikut.

Tabel 2. Kriteria Ketuntasan Belajar Siswa

\begin{tabular}{|c|c|}
\hline Kriteria Ketuntasan Belajar & Rentangan Persentase \\
\hline Sangat Baik & $80 \leq \mathrm{E} \leq 100$ \\
\hline Baik & $70 \leq \mathrm{E}<80$ \\
\hline Cukup & $60 \leq \mathrm{E}<70$ \\
\hline Kurang & $40 \leq \mathrm{E}<60$ \\
\hline Sangat Kurang & $0 \leq \mathrm{E}<40$ \\
\hline
\end{tabular}

\section{Hasil Penelitian}

\section{Hasil Observasi Aktivitas Siswa}

Berdasarkan analisis observasi pada siklus I dan siklus II, diperoleh data adanya peningkatan aktivitas belajar siswa dari ketujuh indikator aktivitas belajar siswa yang diamati. Berikut merupakan persentase aktivitas belajar pada siklus I dan siklus II berdasarkan indikator. Persentase aktivitas belajar siswa pada siklus I adalah $54,94 \%$ mengalami peningkatan pada siklus II menjadi $63,65 \%$.

Tabel 3. Persentase Aktivitas Belajar Siswa pada Siklus 1 dan Siklus 2

\begin{tabular}{|c|c|c|c|}
\hline \multirow[t]{2}{*}{ No. } & \multirow[t]{2}{*}{ Indikator Aktivitas } & \multirow[b]{2}{*}{ Siklus 1} & \multirow[b]{2}{*}{ Siklus 2} \\
\hline & & & \\
\hline 1 & Memperhatikan penjelasan guru & 58,7 & 75,9 \\
\hline 2 & $\begin{array}{l}\text { Menjawab pertanyaan } \\
\text { kontekstual }\end{array}$ & 58,7 & 70,1 \\
\hline 3 & $\begin{array}{l}\text { Menyelesaikan masalah } \\
\text { menggunakan alat peraga }\end{array}$ & 51,9 & 65,3 \\
\hline 4 & $\begin{array}{l}\text { Interaksi dengan guru dan siswa } \\
\text { lain }\end{array}$ & 56,7 & 69,2 \\
\hline 5 & Mengikuti diskusi dengan aktif & 56,7 & 73,07 \\
\hline 6 & Mempresentasikan hasil diskusi & 50 & 60,5 \\
\hline 7 & Menyimpulkan & 51,9 & 61,5 \\
\hline & Rata-rata & 54,94 & 63,65 \\
\hline
\end{tabular}

2. Hasil Observasi Aktivitas Guru
Ada 13 indikator yang diamati oleh Guru kelas terhadap aktivitas peneliti di dalam kelas. Berdasarkan analisis observasi pada siklus I dan siklus II, diperoleh data adanyapeningkatan aktivitas Guru dari ketigabelas indikator aktivitas guru yang diamati. Berikut merupakan data aktivitas guru pada siklus I dan siklus II berdasarkan indikator.

Tabel 4. Hasil Observasi Aktivitas Guru

\begin{tabular}{|c|c|c|c|}
\hline \multirow{2}{*}{ No } & \multirow[t]{2}{*}{ Indikator Kegiatan Peneliti } & \multicolumn{2}{|c|}{ Skor } \\
\hline & & Siklus I & Siklus II \\
\hline 1 & $\begin{array}{l}\text { Mengadakan tanya jawab seputar } \\
\text { materi yang akan disampaikan } \\
\text { dan mengaitkan dengan } \\
\text { kehidupan sehari-hari. }\end{array}$ & 4 & 4 \\
\hline 2 & Memotivasi siswa & 3 & 4 \\
\hline & $\begin{array}{l}\text { Menyampaikan tujuan } \\
\text { pembelajaran }\end{array}$ & 4 & 4 \\
\hline 4 & $\begin{array}{l}\text { Membagi siswa di kelas ke } \\
\text { dalam beberapa kelompok }\end{array}$ & 4 & 5 \\
\hline & $\begin{array}{l}\text { Memberikan masalah } \\
\text { kontekstual mengenai layang- } \\
\text { layang. }\end{array}$ & 4 & 4 \\
\hline 6 & $\begin{array}{l}\text { Menyediakan alat peraga bagi } \\
\text { setiap kelompok }\end{array}$ & 3 & 5 \\
\hline & $\begin{array}{l}\text { Menugaskan tiap kelompok } \\
\text { untuk bekerjasama mengerjakan } \\
\text { LKK }\end{array}$ & 4 & 5 \\
\hline & $\begin{array}{l}\text { Memberi kesempatan kepada } \\
\text { setiap siswa untuk menemukan } \\
\text { kembali konsep dan membangun } \\
\text { idenya sendiri. }\end{array}$ & 4 & 4 \\
\hline 2 & $\begin{array}{l}\text { Guru memantau pekerjaan setiap } \\
\text { kelompok dan memberi } \\
\text { bimbingan kepada setiap } \\
\text { kelompok jika ada kesulitan } \\
\text { mengerjakan LKK. }\end{array}$ & 3 & 5 \\
\hline 10 & $\begin{array}{l}\text { Guru meminta perwakilan setiap } \\
\text { kelompok untuk maju ke depan } \\
\text { kelas untuk membandingkan } \\
\text { hasil kerjanya. }\end{array}$ & 4 & 4 \\
\hline 11 & $\begin{array}{l}\text { Memberikan kesempatan kepada } \\
\text { siswa untuk bertanya. }\end{array}$ & 4 & 5 \\
\hline 12 & $\begin{array}{l}\text { Membimbing siswa untuk } \\
\text { menarik kesimpulan. }\end{array}$ & 4 & 4 \\
\hline 13 & $\begin{array}{l}\text { Memberikan refleksi di akhir } \\
\text { pembelajaran. }\end{array}$ & 3 & 4 \\
\hline & Jumlah Skor yang dicapai & 48 & 52 \\
\hline & Jumlah Skor maksimal & 65 & 65 \\
\hline & Persentase $(\%)$ & 73,84 & 80 \\
\hline
\end{tabular}

3. Hasil Belajar Siswa 
Berdasarkan Tabel 5 di bawah ini, dapat dilihat mana hasil belajar sangat baik mengalami peningkatan sebesar $23,07 \%$. Siswa dengan kriteria hasil belajar baik juga mengalami peningkatan dari $15,38 \%$ menjadi $26,92 \%$. Siswa dengan hasil belajar cukup mengalami penurunan dari $26,92 \%$ menjadi $15,38 \%$. Siswa dengan hasil belajar kurang baik meningkat dari $26,92 \%$ menjadi $34,61 \%$. Siswa dengan hasil belajar sangat kurang baik mengalami penurunan dari $30,76 \%$ menjadi 0 .

Tabel 5. Persentase Kriteria Hasil Belajar Siswa pada Siklus 1 dan Siklus 2

\begin{tabular}{|c|l|c|c|c|c|}
\hline \multirow{2}{*}{ No. } & \multirow{2}{*}{$\begin{array}{c}\text { Kriteria Hasil } \\
\text { Belajar }\end{array}$} & \multicolumn{2}{|c|}{ Siklus 1 } & \multicolumn{2}{c|}{ Siklus 2 } \\
\cline { 3 - 6 } & $\begin{array}{c}\text { F } \\
\text { Siswa }\end{array}$ & $\begin{array}{c}\text { Persentase } \\
\mathbf{( \% )}\end{array}$ & $\begin{array}{c}\text { F } \\
\text { Siswa }\end{array}$ & $\begin{array}{c}\text { Persentase } \\
(\%)\end{array}$ \\
\hline 1 & Sangat Baik & 0 & 0 & 6 & 23,07 \\
\hline 2 & Baik & 4 & 15,38 & 7 & 26,92 \\
\hline 3 & Cukup & 7 & 26,92 & 4 & 15,38 \\
\hline 4 & Kurang & 7 & 26,92 & 9 & 34,61 \\
\hline 5 & Sangat Kurang & 8 & 30,76 & 0 & 0 \\
\hline \multicolumn{2}{|c|}{ Jumlah } & 26 & 100 & 26 & 10 \\
\hline
\end{tabular}

\section{Pembahasan}

Pembelajaran matematika realistik pokok bahasan luas trapesium dan layang-layang pada siswa kelas V SDN Antirogo 01 Jember sudah terlaksana dengan baik. Hasil observasi sebelum diadakan tindakan menunjukkan bahwa aktivitas belajar siswa rendah, karena pembelajaran masih terpusat pada guru. Siswa jarang dilibatkan saat pembelajaran berlangsung, sehingga berdampak juga pada hasil belajar siswa yang masih rendah karena siswa mengalami kesusahan dalam memahami materi yang dijelaskan guru. Hasil dari observasi awal ini digunakan sebagai dasar untuk merancang pembelajaran dengan menggunakan pendekatan PMR pada siklus I dan siklus II. Pelaksanaan siklus I dan siklus II diikuti oleh semua siswa kelas V SDN Antirogo 01 Jember sebanyak 26 siswa.

Pembelajaran dilakukan secara terprogram, yang mana guru telah menyiapkan media, LKS/LKK, membentuk kelompok yang heterogen, dan melaksanakan pembelajaran berdasarkan RPP yang telah disusun. Hal tersebut telah sesuai dengan pendapat Dimyati dan Mudjiono [6] yang menyatakan bahwa pembelajaran adalah penekanan penyediaan sumber belajar untuk membuat siswa belajar secara aktif melalui kegiatan guru yang terprogram dalam desain instruksional.

Pada siklus I, terdapat beberapa kelompok yang kelihatan kebingungan dalam mengerjakan LKK dan juga ada 2 kelompok yang siswanya hiperaktif, sehingga mereka lebih banyak bermain dan mengganggu kelompok lainnya ketika mengerjakan LKK. Hal tersebut diakibatkan pembagian kelompok yang kurang merata. Penerapan PMR memberikan hasil yang baik. Apabila dilihat pada siklus 1, ketuntasan belajar siswa masih belum dikatakan berhasil karena ketuntasan belajar siswa secara klasikal mencapai 42,3\% atau sebanyak 11 siswa yang berhasil mencapai KKM atau tuntas dan 15 siswa yang lain belum tuntas. Oleh sebab itu, penelitian dilanjutkan pada siklus 2. Dari 1 pertemuan yang telah dilaksanakan pada siklus 2, diperolah hasil belajar yang cukup memuaskan yaitu $65,38 \%$ atau sebanyak 17 siswa yang tuntas dan sisanya 9 siswa belum tuntas. Sementara itu, rata-rata hasil belajar siswa mengalami peningkatan yang pada siklus 1 sebesar 56,92 meningkat menjadi 71,15 pada siklus 2 .

Dalam penerapan PMR, guru memberikan kesempatan pada peserta didik untuk berbuat atau beraktivitas agar pembelajaran lebih bermakna. Hasil observasi aktivitas guru pada siklus 1, secara umum aktivitas guru dalam membimbing diskusi kelas, mendorong siswa interaktif (bertanya atau memberikan tanggapan selama pembelajaran), dan memberikan refleksi diakhir pembelajaran masih kurang. Untuk itu perlu pembenahan dan mencari strategi yang tepat, sehingga pada siklus 2 secara umum keseluruhan aktivitas guru mengalami peningkatan. Peningkatan terjadi di segala aspek, tetapi yang paling signifikan terjadi pada aspek mendengarkan penjelasan dari guru. Para siswa sudah mulai terbiasa dengan kehadiran peneliti di kelas, sehingga timbullah sikap hormat yang mana mereka sudah menurun tingkat ramainya tidak seperti ketika awal peneliti masuk kelas. Pada siklus I, aktivitas mendengarkan penjelasan dari guru mendapat nilai 58,7 kemudian masuk ke siklus II menjadi 75,9. Berdasarkan hasil observasi aktivitas siswa dalam mengikuti pembelajaran matematika realistik pada siklus I, indikator paling rendah yaitu 50 adalah aktivitas "mempresentasikan hasil diskusi" yang mana mereka masih terlihat canggung dan masih takut dalam menyampaikan hasil diskusinya. Mereka masih saling menunjuk antar anggota kelompoknya untuk mempresentasikan hasil diskusinya. Untuk itu guru perlu memberikan motivasi dan penghargaan kepada siswa yang telah berani untuk mempresentasikan hasil diskusinya. Rata-rata persentase aktivitas belajar siswa pada siklus I sebesar 51,9 menunjukkan bahwa secara klasikal siswa dikategorikan kurang aktif dan pada siklus II, rata-rata aktivitas belajar siswa meningkat menjadi 63,65 yang menunjukkan secara klasikal aktivitas siswa dikategorikan cukup aktif. Pada siklus II secara umum terjadi peningkatan pada semua indikator.

Berdasarkan pembahasan yang telah diuraikan di atas, hasil penelitian yang didapatkan, yakni pembelajaran matematika realistik dapat meningkatkan hasil belajar siswa. Hal tersebut sama dengan hasil penelitian yang dilakukan oleh Asvina (2012) dan Sofiana (2015), Selain itu, hasil penelitian juga menunjukkan bahwa PMR dapat meningkatkan aktivitas belajar siswa. Hasil penelitian tersebut sama dengan hasil penelitian oleh Wahyuningsih (2015). Adapun materi yang membedakan penelitian terdahulu dengan penelitian sekarang yaitu materi penelitian terdahulu diantaranya: a) luas trapesium dan layang-layang; b) pecahan, dan c) geometri dan pengukuran; sedangkan materi penelitian yang sekarang adalah luas trapesium dan layang-layang.

\section{Kesimpulan dan Saran}

Berdasarkan hasil penelitian yang telah dilakukan, maka dapat disimpulkan bahwa: a) Penerapan pendekatan 
pembelajaran matematika realistik (PMR) pada pokok bahasan luas trapesium dan layang-layang berjalan dengan baik. Hal ini terlihat dari hasil analisis aktivitas guru pada siklus I dan siklus II mencapai angka 80\%. Guru mengalami kesulitan pada fase mempresentasikan hasil kerja karena para siswa masih belum terbiasa untuk melakukan kegiatan tersebut, sehingga siswa masih malu untuk bertanya maupun mengutarakan pendapatnya sedangkan peningkatan pada siklus I dan siklus II ini terletak pada memperhatikan penjelasan guru, dimana para siswa sudah bisa untuk tertib dan menghormati guru yang sedang memberikan penjelasan dan pada indikator interaksi dengan guru dan siswa lain dimana setiap siswa mulai aktif untuk bertukar pikiran dengan kelompoknya serta tidak malu untuk bertanya ke guru ketika ada kesulitan. b) Aktivitas belajar siswa dengan menerapkan pembelajaran matematika realistik pada pokok bahasan luas trapesium dan layang-layang mengalami peningkatan. Rata-rata persentase aktivitas belajar siswa meningkat dari $54,94 \%$ pada siklus 1 menjadi $63,65 \%$ pada siklus 2. Aktivitas guru dalam menerapkan pembelajaran matematika realistik juga mengalami peningkatan dari $73,84 \%$ pada siklus 1 menjadi $80 \%$ pada siklus 2 , dan c) Hasil belajar siswa dengan menerapkan pembelajaran matematika realistik pada pokok bahasan luas trapesium dan layang-layang mengalami peningkatan. Rata-rata hasil belajar siswa meningkat dari 56,92 pada siklus 1 menjadi 71,15 pada siklus 2 . Ketuntasan belajar siswa juga mengalami peningkatan dari $71,9 \%$ pada siklus $1 /$ menjadi $84,4 \%$ pada siklus 2 .

Saran yang perlu dipertimbangkan melalui hasil penelitian ini adalah hendaknya menerapkan pendekatan PMR tidak hanya pada materi luas trapesium dan layanglayang, namun alangkah baiknya diterapkan pada materi dan mata pelajaran lain dengan memperhatikan materi yang cocok. Bagi peneliti lain, melalui hasil penelitian ini agar dapat dijadikan referensi dalam melakukan penelitian selanjutnya khususnya yang berkaitan dengan upaya meningkatkan aktivitas dan hasil belajar melalui pendekatan pembelajaran matematika realistik. Perbaikan-perbaikan juga dilakukan untuk penelitian selanjutnya. Bagi instansi terkait (SDN Antirogo 01) agar dapat mempertimbangkan kebutuhan siswa dalam mendalami suatu materi, seperti media pembelajaran macam-macam bentuk bangun datar supaya memudahkan proses pembelajaran geometri dengan menerapkan pendekatan pembelajaran matematika realistik. Guru harus lebih kreatif lagi dalam membuka pelajaran, misalnya dengan menggunakan media bangun datar yang ada di sekitar siswa. Guru harus memberi motivasi agar siswa lebih berani untuk menjawab dan mengungkapkan pendapat. Guru lebih intensif dalam membimbing siswa dalam mengerjakan LKK.

\section{Daftar Pustaka}

[1] Susanto, A. 2013. Teori belajar dan pembelajaran di Sekolah Dasar. Jakarta. Prenadamedia Group.

[2] Sugiarti, T. 2002. Pembelajaran Matematika dengan Pendekatan Matematika Realistik dalam Jurnal Saintifikasi (Vol 3 No.1). Jember : FKIP Universitas Jember.

[3] Hobri. 2009. Model-Model Pembelajaran Inovatif. Jember: Center for Society Studies.
[4] Arikunto, S. Penelitian Tindakan Kelas. Jakarta: Bumi Aksara.

[5] Masyhud, M. Sulthon. 2014. Metode Penelitian Pendidikan. Jember. Lembaga Pengembangan Manajemen dan Profesi Pendidikan.

[6] Dimyati dan Mudjiono. 2013. Belajar dan Pembelajaran. Jakarta. PT Asdi Mahasatya 